\title{
The Type of Sentence in The Essays of Grade VI Elementary School Students in Bali Province: A Syntactic Study
}

\author{
Ida Bagus Putrayasa \\ Ganesha University of Education \\ Bali, Indonesia \\ ibputra@gmail.com
}

\author{
Dewa Putu Ramendra \\ Ganesha University of Education \\ Bali, Indonesia
}

\author{
Ida Bagus Putra Manik Aryana \\ Ganesha University of Education \\ Bali, Indonesia
}

\begin{abstract}
In written communication, the sentences used by students tend to be less varied. The lack of variability appears in the types of sentences used in the essay, such as: the content of the sentence, the number of clauses, the predicate formers, and the nature of actor-action relationship. Based on this situation, the main objective of this study was to describe the types of sentences contained in the essay of grade VI students in the province of Bali. The data were collected through document recording method of 120 articles, each consisting of 3 paragraphs. The data collected were analyzed through Putrayasa analysis model. The results showed that there were 1035 sentences. All the sentences employed declarative sentences. The declarative sentences consist of 510 simple sentences, 520 compound sentences, and 5 sentences not including both; 876 included verbal sentences, 159 nominal sentences; 798 were classified as active and 237 passive sentences. Based on the results obtained, it is suggested to the students to pay attention always to the type of sentence in writing essay for the effectiveness of the ideas conveyed.
\end{abstract}

Keywords—syntactic study; sentence type; essay

\section{INTRODUCTION}

One of the syntactic studies is a sentence. Therefore, the study of syntax cannot be separated from the theory of sentences itself. A sentence is a string of words that has a complete idea (Collin \& Stabler, 2016; Osborne, et.al, 2012; ). In the string of words lies the ideas conveyed, which are minimally represented through the subject and predicate elements (Batterink \& Neville, 2013; Putrayasa, 2016; 2017). The elements of the sentence have a harmony between the formers, the harmony of the subject with the predicate, the harmony of the predicate with the object, the harmony of the predicate with the adverb (Robert-Burton, 1997; Putrayasa, 2014a). In addition to the harmony, another aspect to be considered in the sentence is the type of sentence used, the sentence unity, and the sentence structure used in conveying the ideas (Clifton \& Frevier, 2010; Putrayasa, 2017b).
Syntax is a sequence of words that make sense (Reyner, 2016; Collins \& Stabler, 2016; Robert-Burton, 1997; Vallin \& LaPolla, 1997). Meanwhile, another opinion stated that syntax is the relationship between one word with another word. These interrelationships form an understanding (Putrayasa, 2014a; $2014 b ; 2014 c)$. Syntax is a discipline whose study is focused on a word string consisting of S-P-O which contains a complete understanding (Thornoboy, 2009; Tallerman, 2011; Putrayasa, 2014c). However, the word string is often discovered without a full comprehension, both used in oral communication and written communication. One of these written communications is in the student essay. A composition is a combination of several interconnected sentences, containing ideas. This essay will be used only as a means to examine the sentences used by students in their essay. In composing, students use a string of words to convey their ideas, but there are some that do not contain a complete idea. This incomplete understanding is shown without the presence of a Subject or Predicate. In addition to the string of words which does not contain a complete idea, the sentences are sometimes less varied, so less effective. This is what makes the sudents'compositions interesting to study from the sentence type aspects, the sentence unity, and the sentence structure. These aspects can refine the syntactic study in the students' essay. In his research on syntax, especially sentences, Putrayasa (2008) reveals that students still have difficulty to determine word function in sentence structure, whether as subject, predicate, object, complement, or adverb in sentence.

There were several studies that discussed syntax, among others: Putrayasa (2008, 2010, 2014), Maimunah (2014), and Baryadi (2014). The studies that had been conducted did not discuss in detail matters relating to sentence type, sentence unity and sentence structure. Putrayasa's research (2008) which was conducted in Singaraja city only studied subjects and predicate in student essay through qualitative and quantitative approach. In 2010, research on syntactic studies 
was done again, but only studied the mastery of students in distinguishing elements of objects and complements. Maimunah's study (2014) only examines clauses in terms of functions, categories, and roles in the Surah Al-Qari'ah's translation. The study has not been comprehensive, has not investigated on the type of sentences in the Surah Al-Qari'ah's translation. Meanwhile, a research conducted by Baryadi (2014) only discussed the sequence of clauses in subordinative compound sentences in Indonesian language studied from a syntactic perspective.

A fairly comprehensive research related with the study of syntax, especially sentence elements but done separately, also conducted by Putrayasa (2015). His research examines the different elements of objects and adverbial. The results show that students' ability is still low (average: 5.75) in determining the elements of the sentences. This is due to the low understanding of students on the concept of sentences, the concept of the elements that form sentences in terms of type, unity, and structure. Added by the lack of exercises on how to determine the elements of the sentence. With such lack of understanding and practice, this will have an impact on the low quality of the language used in conveying ideas, both orally and in writing.

Based on the above description of the background, the making of a study and theory about syntax, especially regarding the type of sentence, would be urgent to do. This study has a strategic position as a basis for further research development and can be practically used as a reference of knowledge in delivering ideas orally or in writing. As a description of the earlier research and statements of earlier scholars and researchers, the mastery of syntax (especially sentences) can be understood in at least through three study aspects: the sentence type, the sentence unity, and the sentence structure. However, in this paper the study is only related to the type of sentence in the essay of grade VI students in the province of Bali. The main problem in this research is: what kind of sentence is in the essay of the grade VI of elementary school students in Bali province? The main problem can be broken down into four issues, namely How (1) the type of sentence based on its content, (2) the type of sentence based on the number of clauses, (3) the type of sentence based on the predicate former, and (4) the type of sentence based on the nature of actor-action relationship, in the essay of grade VI students in the province of Bali.

\section{METHOD}

The design used in this research is descriptive qualitative design. The source of this research data is the essay of grade VI students in the province of Bali. The sample determination used random area sampling technique, namely random to elementary school representing North Bali, South Bali, West Bali, and East Bali. Each of these areas will be represented by Buleleng Regency representing North Bali, Tabanan representing South Bali, Jembrana representing West Bali, and Karangasem representing East Bali. From each district will be taken 3 elementary schools, each with good category, medium, and less. Of each elementary school will be taken 10 students' essays. Thus, there was a total of 12 elementary schools and
120 student essays as the samples of year I as shown in the table I below.

TABlE I. SCHOOL SAMPLES AND ThE STUdENTS' EsSAY

\begin{tabular}{|r|l|c|c|}
\hline \multicolumn{1}{|c|}{ No. } & \multicolumn{1}{|c|}{ District } & $\begin{array}{c}\text { The Number of } \\
\text { Elementary } \\
\text { Schools }\end{array}$ & $\begin{array}{c}\text { The Number of } \\
\text { Students' Essays }\end{array}$ \\
\hline 1 & Buleleng & 3 & 10 \\
\hline 2 & Tabanan & 3 & 10 \\
\hline 3 & Jembrana & 3 & 10 \\
\hline 4 & Karangasem Total & 3 & 10 \\
\hline \multicolumn{2}{|r|}{} & 12 & 120 \\
\hline
\end{tabular}

The method used in collecting data is document recording method. The data collected were analyzed through Putrayasa analysis model.

\section{RESULTS AND DISCUSSION}

In this section the results of the study are presented in accordance with the problems studied, namely the type of sentence based on: (1) the content, (2) the number of clauses, (3) predicate formers, and (4) the nature of actor-action relationship in the essays of grade VI elementary schools students in Bali province.

The source of data studied comes from the essays of grade VI elementary schools students in Bali province. The total number of articles is 120, each of which consists of 3 paragraphs. The sum of all sentences is 1035 . The whole sentences are examined from the aspect of the contents, the number of clauses, the predicate formers, and the nature of actor-action relations, as shown in the description below.

Based on the data analysis conducted, it found the type of sentence in the essay of grade VI elementary school students as shown in Table II below.

TABLE II. THE TYPES OF SENTENCES IN GRADE VI ELEMENTARY SCHOOLS STUDENTS IN BALI PROVINCE.

\begin{tabular}{|c|c|c|c|c|c|c|}
\hline \multirow[b]{2}{*}{ No. } & \multicolumn{4}{|c|}{ Sentence Type Based on ... } & \multirow{2}{*}{$\begin{array}{c}\text { Frequ- } \\
\text { ency }\end{array}$} & \multirow{2}{*}{$\begin{array}{l}\text { To } \\
\text { tal }\end{array}$} \\
\hline & Content & $\begin{array}{c}\text { The } \\
\text { Number of } \\
\text { Clauses }\end{array}$ & $\begin{array}{l}\text { Predicate } \\
\text { Formers }\end{array}$ & $\begin{array}{l}\text { The Nature of } \\
\text { Actor-action } \\
\text { Relationship }\end{array}$ & & \\
\hline 1 & $\begin{array}{l}\text { Declarative } \\
\text { Sentence }\end{array}$ & - & - & - & 1035 & \multirow{3}{*}{$\begin{array}{l}10 \\
35\end{array}$} \\
\hline 2 & $\begin{array}{l}\text { Interogative } \\
\text { Sentence }\end{array}$ & - & - & - & $\mathbf{0}$ & \\
\hline 3 & $\begin{array}{l}\text { Imperative } \\
\text { Sentence }\end{array}$ & - & - & - & $\mathbf{0}$ & \\
\hline 4 & & $\begin{array}{l}\text { Simple } \\
\text { Sentence }\end{array}$ & - & - & 510 & \multirow{3}{*}{$\begin{array}{l}10 \\
35\end{array}$} \\
\hline 5 & & $\begin{array}{l}\text { Compound } \\
\text { Sentence }\end{array}$ & - & - & 520 & \\
\hline 6 & & Not Both & & & 5 & \\
\hline 7 & & & $\begin{array}{l}\text { Verbal } \\
\text { Sentence }\end{array}$ & - & 876 & \multirow[t]{2}{*}{$\begin{array}{l}10 \\
35\end{array}$} \\
\hline 8 & & & $\begin{array}{l}\text { Nominal } \\
\text { Sentence }\end{array}$ & - & 159 & \\
\hline 9 & & & & Active Sentence & 798 & \multirow{2}{*}{$\begin{array}{l}10 \\
35\end{array}$} \\
\hline 10 & & & & $\begin{array}{l}\text { Passive } \\
\text { Sentence }\end{array}$ & 237 & \\
\hline
\end{tabular}


From the table above, it can be described the followings. Based on its contents, it was found only one type of sentence, namely: declarative sentences that amounted to: 1035 sentences. Based on the number of clauses, it was found two types of sentences, namely: 1) simple sentences as many as: 510 sentences, 2) compound sentences as many as 520 sentences, not both: 5 sentences. Based on the predicate formers, it was found two sentence types, that is 1) verbal sentences: 876 and 2) nominal sentences: 159. Based on the nature of actor-action relationship, it was found two types of sentences, namely: 1) active sentence: 798 and 2) passive sentence: 237 sentences.

In the above explanation, the type of sentence found in the essay of the grade VI elementary school students in Bali Province is only 1035 news sentences. This is natural because the description of the object or the students'personal experience needs to be informed to the audience in order that they know the results of the students' thinking. The only tool used to convey the information is declarative sentences. This is in accordance with the statement of Putrayasa (2012, 2017); Huddleston \& Uren (1981); and Osborne, T. at.al. (2012) that a declarative sentence is a sentence used to convey news or information. This declarative sentence is the most widely used in everyday life, both in conveying scientific or non-scientific information.

The second prominent finding related to the above description is the use of compound sentences in the essays of the grade VI of elementary school students in Bali Province. In the students' essay, more compound sentences, i.e., 520 sentences. This happens because the student in conveying his idea is influenced by his spoken language, not paying attention to sentence writing rules, which is marked by capitalization and ending with punctuation. From that, the sentences became long, consisting of several subjects and several predicates, as shown in the excerpt of the data below.

tak terasa haripun sudah hampir sore sehabis bermain aku dan temanteman berpamitan mau langsung pulang kerumah nenek sesampai disana aku langsung mencari adik sesudah itu aku pulang sesampai diru-

mah aku mandi setelah mandi aku langsung belajar

setelah belajar aku

langsung tidur keesokan harinya aku sekolah sampai di sekolah aku

langsung membaca karangan yang berjudul: hari libur (Kr.1/P3/SD5.J)

The above paragraph is a paragraph that occurs from the word string, which in fact when observed consists of several subjects and predicates following the rules of writing sentences. Because the rules of writing are not followed, then the above paragraphs are not clear in ideas' unity. In order to be clear the unity of the idea, the rule must be met. A sentence's characteristic in terms of writing rules should be marked with capital letters at the beginning of the sentence and end with a punctuation: dot, question, or exclamation mark (Putrayasa, 2012; Robert-Burton, 1997; Nordquist, 2016). By following the existing rules, the sentences that make up the paragraph become clear in the unity of the idea and the paragraph becomes effective.

In addition, grade VI elementary school students tend to construct complex sentences in paragraphs. This happens along with the development of its cognition and language development. The condition is in harmony with the views of Winch, G., at.al. (2006) who stated that between language growth and intellectual growth both are closely intertwined. The more the language is improved, the more the cognitive or intellectual ability it increases. This view is supported by Batterink, L. \& Neville, H.J. (2013) which revealed that the sentences processed and produced by adult children tend to form compound or complex sentences.

The next finding is that almost all sentences used in the grade VI elementary school students in Bali Province are verbal sentences (876 sentences). Verbal sentence is a sentence whose predicate is verb. In the everyday use, more language whose predicate words are verbs were found. There were no exception with the sentences of the essays of grade VI Elementary School students in Bali Province. This shows that human activity in everyday life is doing work. Therefore, the sentences used in everyday communication are verbal sentences. This is in accordance with Putrayasa's opinion (2012) that the type of sentence which is most widely used in everyday communication is a verbal sentence, which is marked by the predicate of the verb. The statement is also supported by the results of research conducted by Hatch (1983) and Putrayasa (2017) which revealed that in the daily life the most human do is working. In language, this work is marked by verbal or verb type.

The last finding is that the use of sentences contained in the sixth graders of elementary school in Bali Province is mostly active (798 sentences). In expressing ideas, students use more active sentences. This happens because in expressing something that is preferred is the subject that does the job. Therefore, the resulting sentence is an active sentence. The active sentence is a sentence whose subject does the job (Nordquist, 2016).

\section{CONCLUSIONS AND RECOMMENDATION}

Based on the results of the description of result and data analysis above, the following conclusions can be put forward. The types of sentences used in grade VI of the Elementary School students in Bali Province studied in terms of: (a) its content, there is only one type of sentence, namely: declarative sentence; (b) the number of clauses, there are two types of sentences, namely: (i) a simple sentence and (ii) a compound sentence; (c) its predicate, there are two types of sentences: (i) verbal sentences and (ii) nominal sentences; and (d) the nature of actor-action relations, there are two types of sentences: (i) active sentences and (ii) passive sentences. Based on the above conclusions, it is suggested to the students to pay attention always to the type of sentence in writing essay for the effectiveness of the ideas conveyed. 


\section{References}

Baryadi, P. (2014). Urutan klausa dalam kalimat majemuk subordinat bahasa Indonesia: Kajian dari Perspektif Sintaksis dan Wacana. Jurnal Sintaksis Lanjut.

Batterink, L. \& Neville, H.J. (2013). The human brain processes syntax in the absence of concious awareness. The Journal of Neuroscien, 33(19): 8528-8533; doi:10, 1523/J/NEUROSCI.0618-13. 2013.

Clifton, C. \& Frazier, L. (2010). Imperfect ellipsis: antecedents beyond syntax? Journal of Syntax, 13 (4), 279-297

Collin, C. \& Stabler, E. (2016). A formalization of minimalist syntax. Journal of Syntax, 19(1) 43-78

Hatch, E.M. (1983). Psycholinguistics: A second language perspective. Tokyo: Newbury Haouse Publishers, Inc.

Huddleston, R.D. \& Uren, O. (1981). Declarative, interogative, and imperative in French. In M.A.K. Halliday \& J.R. Martin (Eds.). Reading in Systemic Linguistics: (237-256). London: Batsford Academic and Education Ltd.

Maimunah, S. (2014). Analisis klausa berdasarkan fungsi, kategori, dan peran pada terjemahan Surah AlQaria'ah Ayat 1-11. Jurnal Sintaksis Lanjut.

Nordquist, R. (2016). Grammar basics: sentences parts and sentences structure. Retreived from http://grammar.about.com/od/rs/fl/sentencestructure.htm.

Osborne, T. at.al. (2012). Catenae: introducing a novel unit of syntactic analysis. Journal of Syntax. 15(4), 354-396,

Putrayasa, I.B. (2008). Tata kalimat. Aksara, Jurnal Bahasa dan Sastra, 32.

Putrayasa, I.B. (2010). Penerapan model konstruktivisme berpendekatan inkuiri dalam pembelajaran bahasa Indonesia (Studi penelusuran miskonsepsi dalam pembelajaran kalimat). Jurnal Pendidikan dan Pengajaran Undiksha, 43(1).

Putrayasa, I.B. (2011). Studi penelusuran miskonsepsi dalam pembelajaran sintaksis (tata kalimat) dengan model konstruktivisme berpendekatan inkuiri pada siswa kelas I SMPN di kota Singaraja, Kabupaten Buleleng, Provinsi Bali. (Proceeding from Konferensi Internasional Masyarakat Linguistik IndonesiaKIMLI-, 2011).
Putrayasa, I.B. (2012). Jenis kalimat dalam bahasa Indonesia. Bandung: Refika Aditama.

Putrayasa, I.B. (2013). Penelusuran miskonsepsi dalam pembelajaran tata kalimat (unsur objek dan pelengkap) dengan pendekatan konstruktivisme berbasis inkuiri. Jurnal Pendidikan Indonesia 2(2).

Putrayasa, I.B. (2014a). Tata kalimat bahasa Indonesia. Bandung: Refika Aditama.

Putrayasa, I.B. (2014b). Analisis kalimat (fungsi, kategori, dan peran). Bandung: Refika Aditama.

Putrayasa, I.B. (2014c). Kalimat efektif (diksi, struktur, dan logika). Bandung: Refika Aditama.

Putrayasa, I.B. (2015). Pembelajaran bahasa Indonesia (kalimat: unsur objek dan adverbial) dengan model konstruktivisme berpendekatan inkuiri. (Proceedings from Seminar Internasional, Malang, 28-29 September 2015).

Putrayasa, I.B. (2017). Sintaksis (memahami kalimat tunggal). Bandung: Refika Aditama.

Putrayasa, I.B. (2017). Penggunaan kalimat pada jurnal ilmiah pendidikan dan pembelajaran program pascasarjana. (Research Report). Singaraja: Universitas Pendidikan Ganesha.

Putrayasa, I.B. (2017b). Unity and effectiveness of the abstract language beginner lecturer research institution (Undiksha) 2015. IOSR Journal of Humanities and Social Science (IOSR-JHSS). 22(3), 23-28, e-ISSN: 2279-0837, p-ISSN: 2279-0845

Reyner, K. (2016). The interaction of syntax and semantic during sentence proccessing: Eye movements in the analysis of semantically based sentences. Departement of Psychology University of Massachussetts, Mass.01003. Published by Elsevier Inc.

Robert-Burton, N. (1997). Analysing sentences. New York: Longman.

Tallerman, M. (2011). Understanding Syntax. London: Hodder Education.

Thornoboy, S. (2009). How to teach grammar. Edinburgh: Pearson Education Limited.

Vallin, R.D.V. \& LaPolla, R.J. (1997). Syntax: structure, meaning, and function. Cambridge: University Press.

Winch, G. et al. (2006). Literacy: reading, writing, and children's literature. (3rd ed.). New York: Oxford. 